\title{
FMARI Application in Innovation and IT for Accidents' Investigation
}

\author{
F. H. Soemidi ${ }^{1, *}$, P. L. Hadi ${ }^{2}$, I. Z. Sutalaksana ${ }^{3}$ \\ ${ }^{1}$ Building Management Division, Research Institution for Human Settlement, Cileunyi, Indonesia \\ ${ }^{2}$ Department of Civil Engineering, Parahyangan Catholic University, Bandung, Indonesia \\ ${ }^{3}$ Department of Industrial Engineering, Bandung Institute of Technology, Bandung, Indonesia
}

Copyright $\bigcirc 2019$ by authors, all rights reserved. Authors agree that this article remains permanently open access under the terms of the Creative Commons Attribution License 4.0 International License

\begin{abstract}
FMARI Database Application is designed to help safety auditor in investigating work accidents and as routine monitoring in regular companies reports to safety board organization in Indonesia (BPJS for Employee) with the main goal is to reach zero accident. FMARI stands for Faktor Manusia dan Analisis Resiko Industri (application: Human Factors and Industrial Risk Analysis) is following HFACS method and make a modification from HFIX in Indonesian terms. The Human Factors Analysis and Classification System (HFACS) is a system-safety model that effectively bridges the gap between human error theory and applied human error analysis. The Human Factors Intervention matriX (HFIX) is an innovative tool for mapping intervention strategies onto the specific forms of human error identified in the HFACS.
\end{abstract}

\section{Keywords FMARI, HFACS, HFIX}

\section{Introduction}

FMARI Database Application is designed to help the safety auditor in investigating work accidents and as routine monitoring in regular companies' reports to the safety board organization in Indonesia (BPJS for Employee and BPJS for Health Insurance) with the main goal is to reach zero accident in high risk jobs.

The number of accidents in Indonesia is among the highest in the ASEAN region. Nearly $32 \%$ of cases of occupational accidents in Indonesia occurred in the construction sector which covers all types of project work buildings, roads, bridges, tunnels, irrigation dams and others. "The construction sector is a supreme contributor to field accidents. Therefore, all construction projects must be supervised, so that number of accidents in construction can be minimized," said Minister of Manpower and Transmigration, during a working visit to the construction projects that are located in apartment of Gandaria City and
Kalibata City, Jakarta, Wednesday (13/1/2010). He added that the purpose of this visit was held to disseminate guidance and supervision Occupational Health and Safety (K3) in the construction sector in supporting the implementation of the National K3 Month campaign which runs from January 12 until February 12 . "From a visit to the construction project, there is a fact that the fundamentals of $\mathrm{K} 3 \mathrm{had}$ been conducted. However, implementation is not perfect, especially on the infrastructure of securing the construction of high rise buildings that need to be improved," said the minister. Figure of occupational accidents in construction services highest compared to the industrial sector, transport and mining. The Ministry of Manpower and Transmigration record until 2010, work accidents still dominated field of construction services $(31.9 \%)$, followed by industry $(31.6 \%)$, transport $(9.3 \%)$, mining $(2.6 \%)$, forestry $(3.8 \%)$, and others $(20 \%)$.

The number of construction accident cases was reported by the construction company to BPJS Employment, has been through internal verification and validation by the Technical Division BPJS within the framework of the development of surveillance applications related to insurance claims by company K3 / victim care through a designated hospital.

K3 management improvement through intervention strategies at all levels, has contributed to a decrease in the number of construction accidents and the government as the labor competency skills builder for construction etc., set the Zero Accident program that must be met by all kinds of companies.

Chairman of the Governing Body Branch (BPC) Gapensi Semarang Devri Alfiandy assess the high number of accidents in the construction sector due to the awareness of the service provider to the safety of workers is still low. It can be seen from members who had taken the certificate of Occupational Safety and Health Management System (SMK3) only around 5\%. "Not all agencies require construction companies so having a certificate that they assess is not part of SMK3 priority," he said, Wednesday 
(13/4). According Devri, work accidents happened mostly in the construction world, where more and more workers, the higher the risk in work accident. The regulations on workplace safety, is already provided for in article 23, paragraph 2 of Law No. 18/1999 Construction Services. Moreover article 11 Regulation No. 9/2008 mentioned MPW service providers shall involve the construction of $\mathrm{K} 3$ expert on every job that has a high risk.

\section{Methodology}

Study based on records 15.154 accident data from BPJS Employee and it is in four work-shifts between from 2007 to 2013. Data is being analyzed with descriptive statistic before it will be transferred in FMARI form of database application and be used to make investigation intervention for safety management system.

Development of taxonomy methods for investigation of human error factor in cases of accidents and incidents of aircraft known as HFACS (Shappell, 2000; Minyamer \& Belay 2018) and HFACS (Human Factors Analysis and Classfication System) get a good response from various practitioners aviation, including: ICAO (International Civil Aviation Organization), GAIN (Global Aviation International Network), IATA (International Air Transport Association), FAA (Federal Aviation Administration) and other aerospace institutions. HFACS is progressing quite rapidly. At first only intended for use in the aviation world was later adopted by other fields, namely shipping (Celic, 2009), mining (Patterson, 2010), railways (Reinach, 2006), and industries such as construction and manufacturing. Human Factors Intervention Matrix (HFIX) is a development HFACS for mapping of intervention strategies that use human error identification form analysis of HFACS and HFIX allow users to systematically build a comprehensive intervention strategy to achieve the target the cause of human error that is in the system. HFIX using nanocode (codes in HFACS) and has already built a database before they can be simulated intervention strategies. HFIX give a scale of 1-5 for every aspect of risk that must be managed and supervised as follows:

1) Feasibility (feasibility - can it be done)

2) Acceptability (operators will accept it)

3) Cost / Efficiency (can we afford it)

4) Effectiveness (will it work)

5) Sustainability (sustainability)

Risk Assessment is the foundation for complishing SMS and the ability in every level of management should be continuously upgraded in the field practices, ie:

- Hazard identification;

- Continuous monitoring and regular assessment upon the level of safety;

- Identification on accidents or incidents to the make sure progress in the level of safety in the future.
Application of Human Factors and Risk Analysis Industry (trial version www.fmari.net ) developed to help safety analyst and cases auditor of occupational accidents in investigating workplace accidents, especially high-risk projects. Based on HFACS and modification efforts HFIX (Human Factors Intervention matrix), then the application FMARI expected to be as analytical tool decision support applications in the company's proposed interventions and monitoring quality improvement, especially Indonesia which do not have application to human error as well as latent failure.

FMARI development in this study conducted by the limitations as follows:

a) Database applications aimed at the context of the safety management system (SMS) construction industry.

b) Aspects examined only in the context of human error alone.

c) Focus on latent failure after failure identified active.

\section{Results}

\subsection{Descriptive Analysis}

There are preliminary results from descriptive statistic, i.e:

1) High rate accident in construction jobs around 2,000 per year and it happened especially in morning shift $(6$ am to $12 \mathrm{am}$ ) followed by (12am to $6 \mathrm{pm}$ ) and then (6pm to $0 \mathrm{am}$ ) last at (1am to $6 \mathrm{am}$ ).
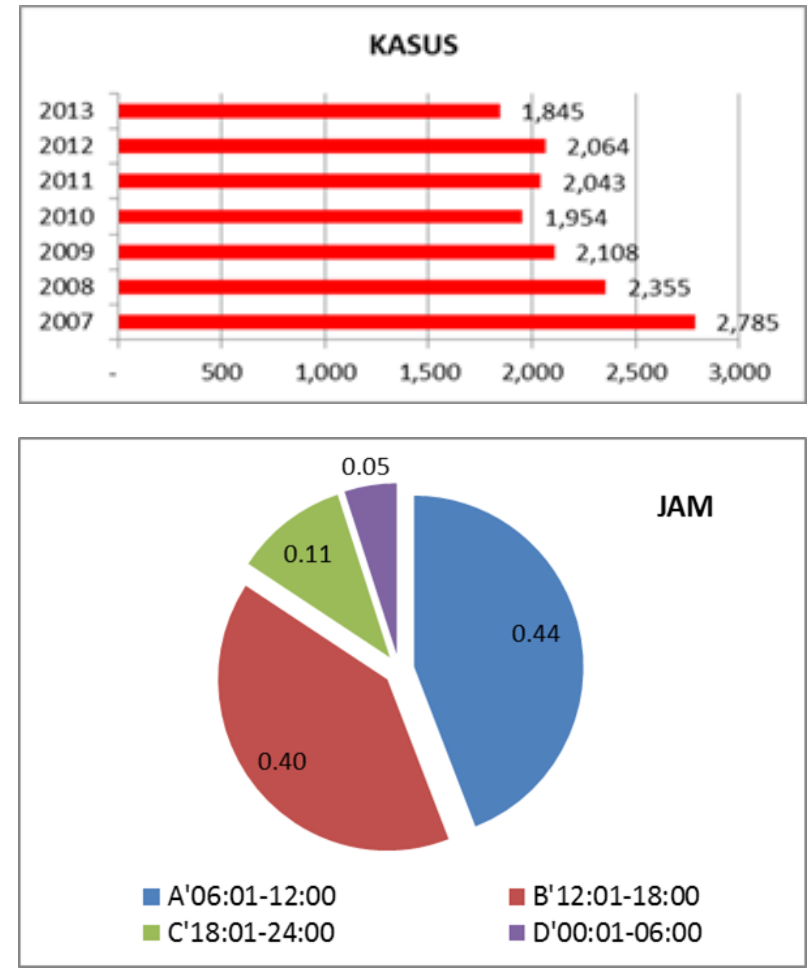
2) Prevalence in sickness $86 \%$, death $9 \%$ and injured $5 \%$.

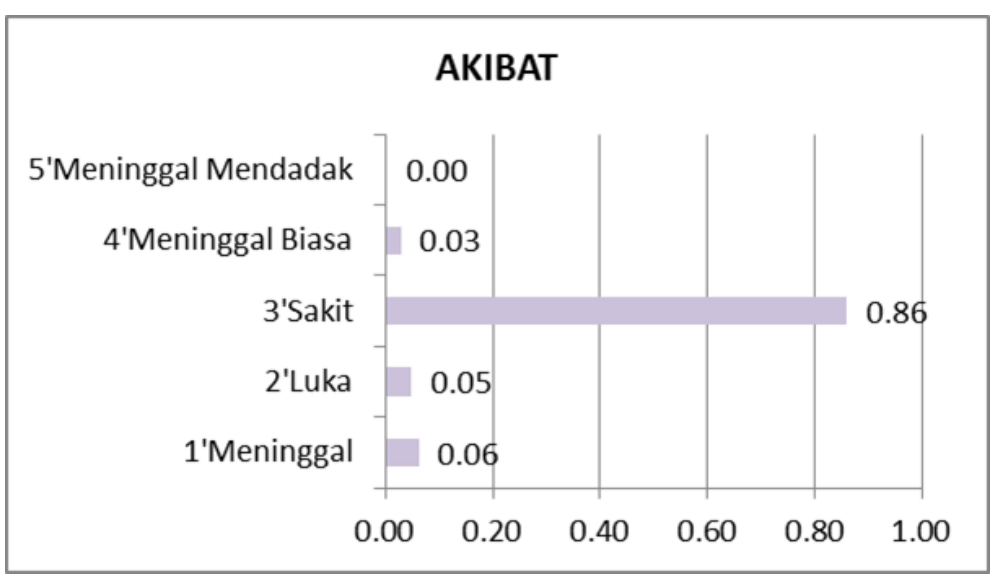

3) Location especially indoor $89 \%$, outdoor $6 \%$ and on streets $5 \%$.

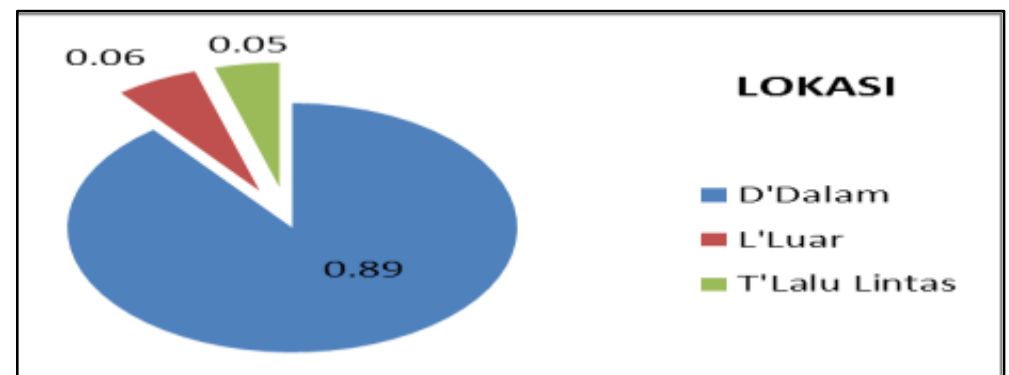

4) Parts of body in accident are head $23 \%$, feet $21 \%$ and fingers $16 \%$.

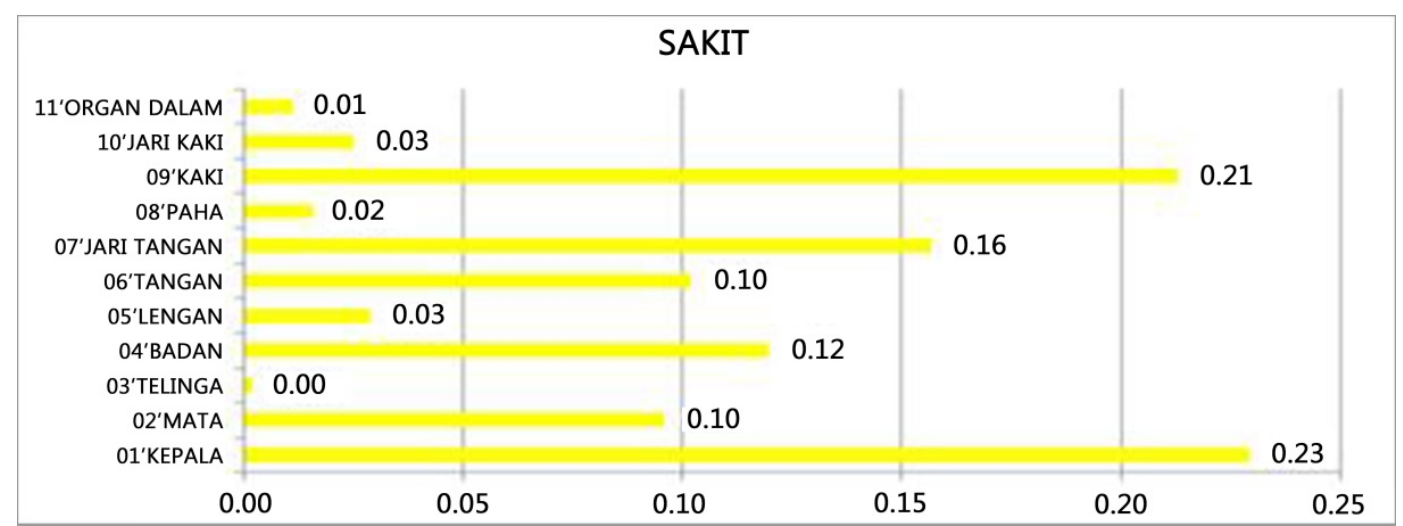

5) Mostly accident are got bumped $46 \%$, trapped $17 \%$ and got hit $14 \%$. 


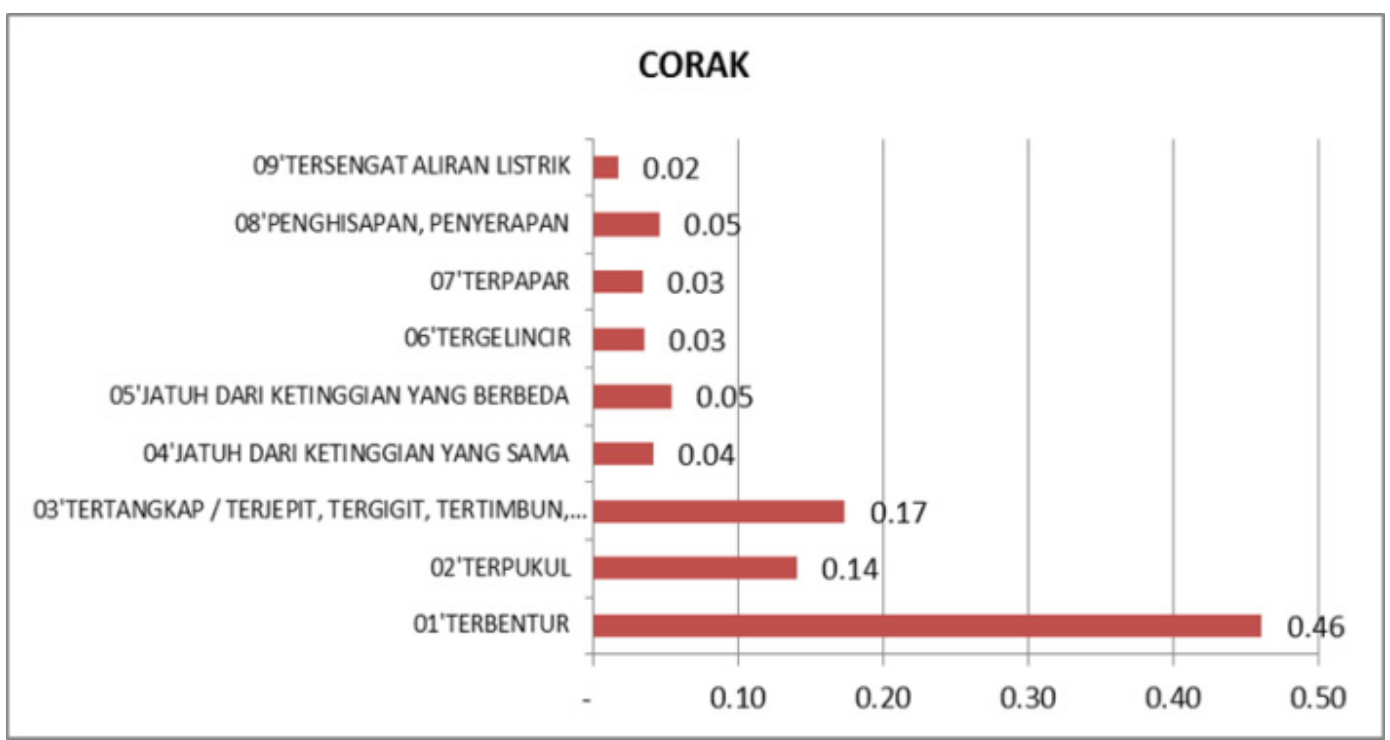

6) Danger situation caused by bad infrastructure 52\%, lack of SOP $18 \%$ and disconnection $5 \%$.

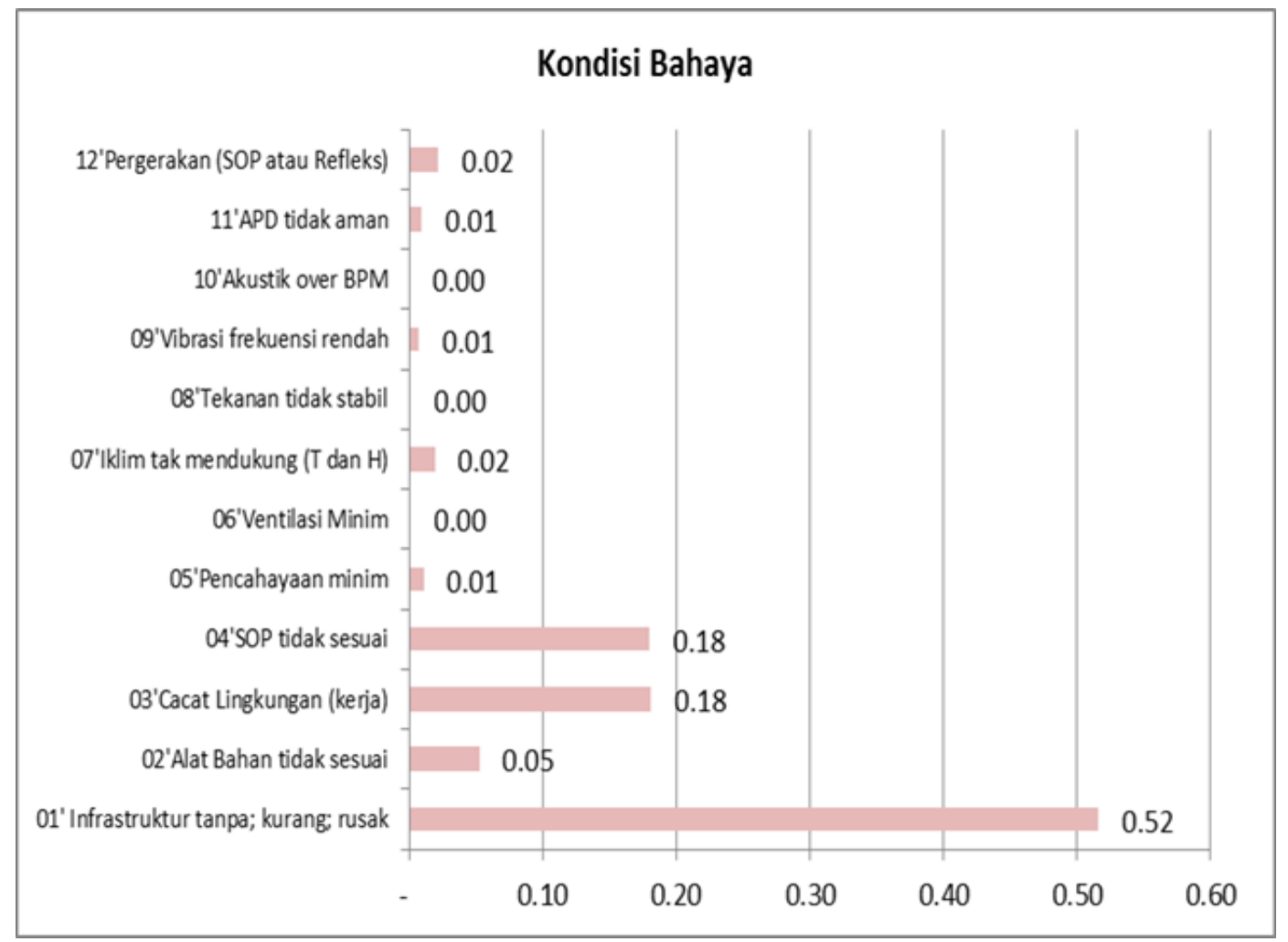

7) Danger action from not safe position 35\%, lack of gear $27 \%$ and high mobilization $11 \%$. 


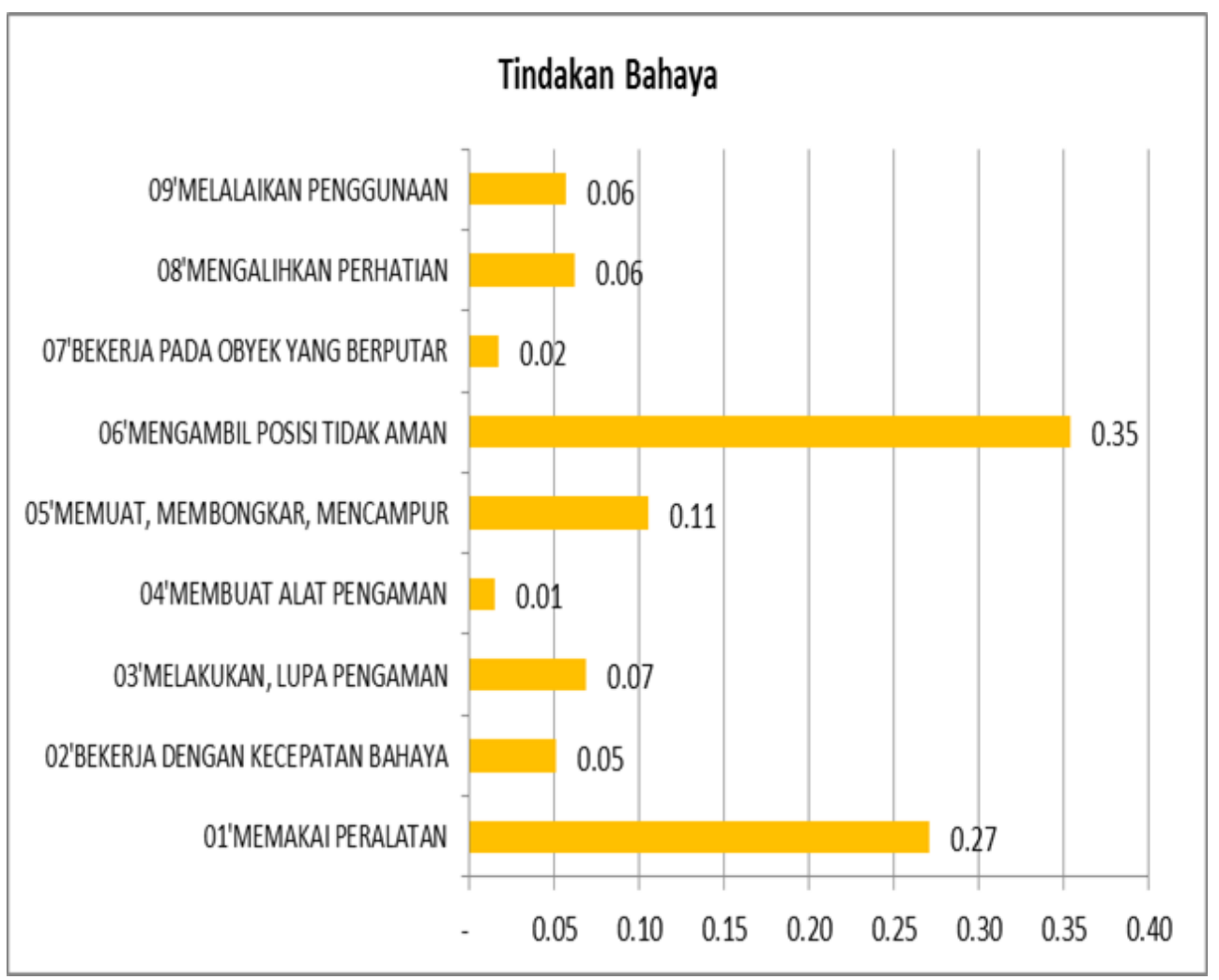

8) Sources of injury are hand tools $27 \%$, machines $19 \%$ and surface of workspace $18 \%$.

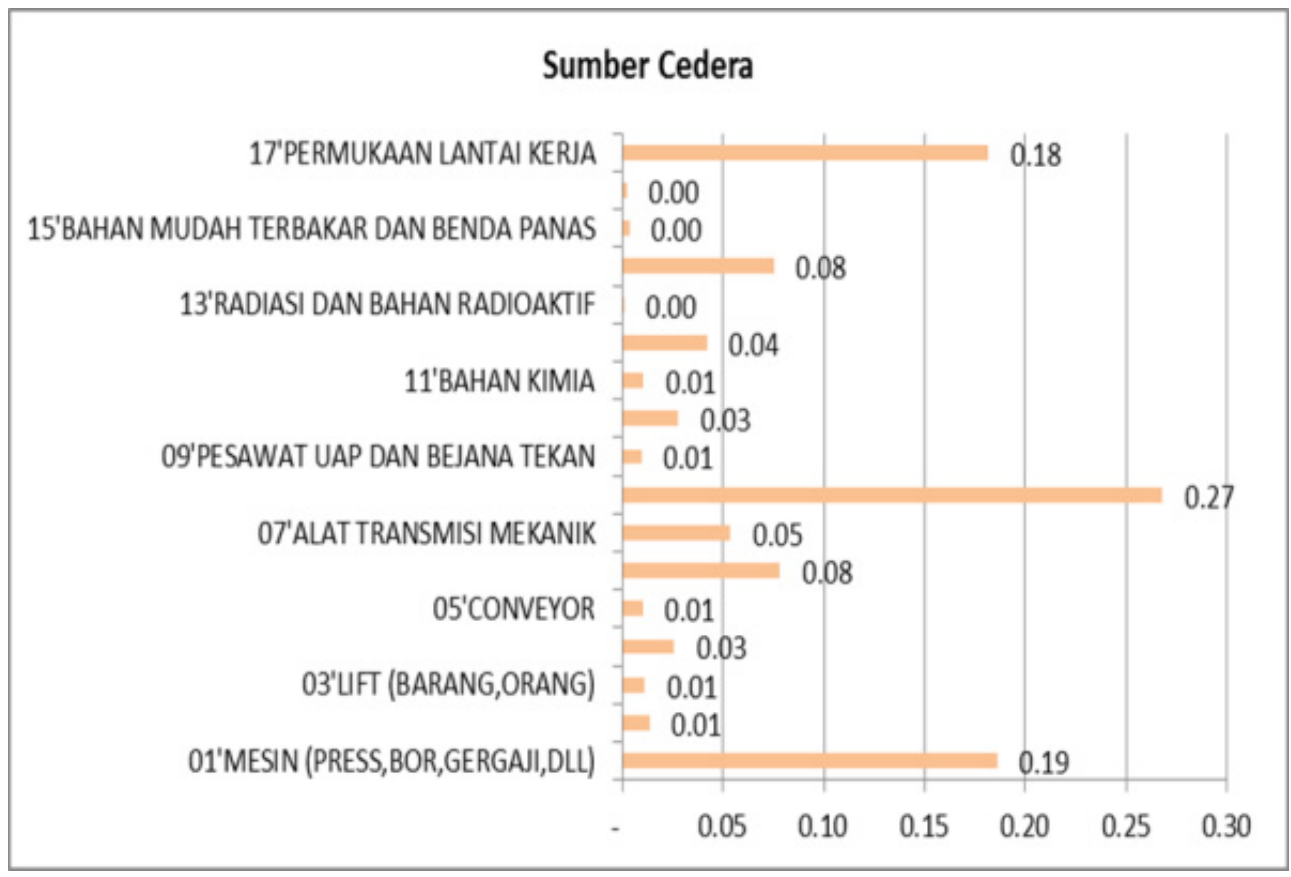

It is still being analyzed in FMARI database application with the modification of HFACS and HFIX with the use of Likert Ranking for Risk Assessment. 
Table 1. Form to Fill in FMARI Database Application
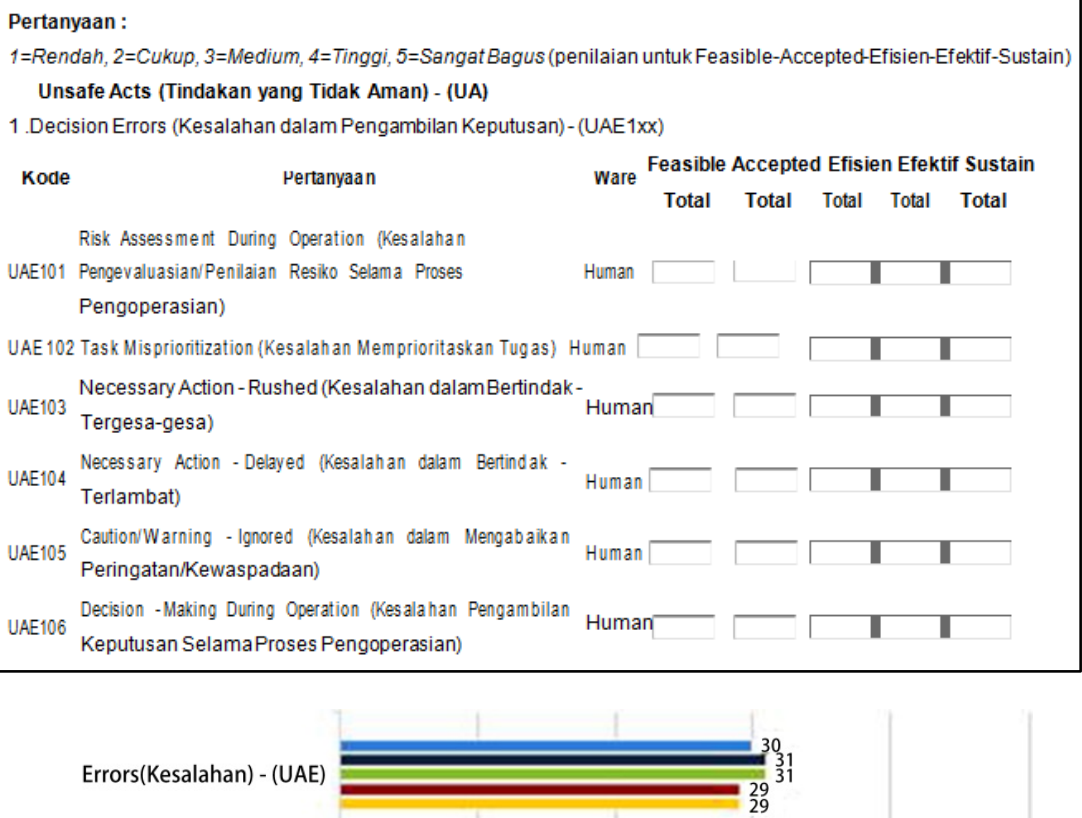

Violations(Pelanggaran) - (UAV)

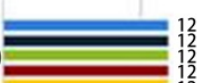

Environmental Factors (Faktor $=$ Lingkungan) - (PEF)

Condition of Operators (Kondisi Operator) - ( $\mathrm{PCO}$

Personnel Factors (Faktor Personel) - (PPF)

Inadequate Supervision Pengawasan yang Tidak Memadai) - (USI $\times \times \times$ )

Planned Inappropriate Operations(Pengoperasian yan Tidak Terencana Dengan 8 aik dan Benar) - (USP $\times \times \times$ )

Failed to Correct Known roblem(Cagal Menyelesaikan Permasalah yang Telah Diketahui)- (USF $\times \times \times$ )

Supervisory Violations (Pelanggaran dalam $\mathrm{Ha}$ Pengawasan)- (USS $\times \times \times$

Resource Management (Manajemen Sumber Daya)

(Manajemen Sumber Daya)
$($ OIR $\times \times \times)$ $(\mathrm{OIR} \times \times \times)$

Organizational Climate (Iklim dan Budaya Organisasi) $(\mathrm{OIC} \times \times \times)$
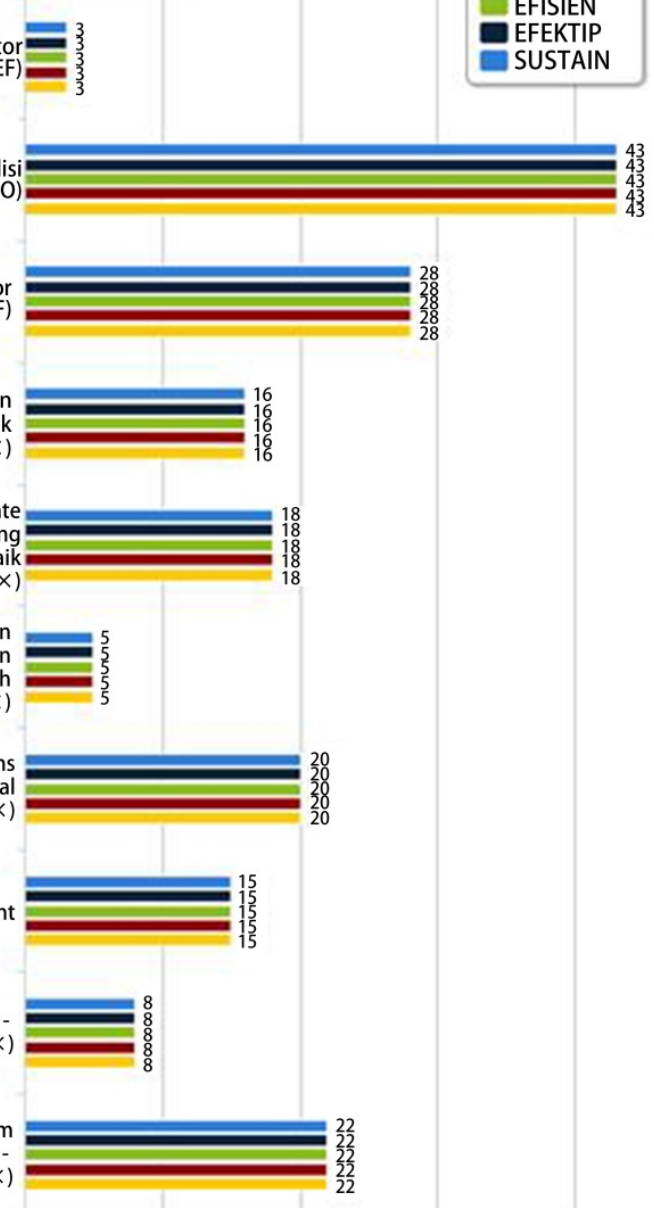

Figure 1. FMARI Analysis for Each Aspect 


\subsection{Reference for FMARI Research}

Table 2. State of the Art

\begin{tabular}{|c|c|c|c|c|c|}
\hline Peneliti & Fokus penelitian & Metode & Partisipan & Material penelitian & Pengukuran \\
\hline $\begin{array}{c}\text { Culver,C.,Marshall,M., \& } \\
\text { Connolly,C,(1993) } \\
\end{array}$ & $\begin{array}{l}\text { Analisis klaim kompensasidari } \\
\text { pekerja konstruksi }\end{array}$ & $\begin{array}{l}\text { Variasi laju jumlah } \\
\text { kecelalaan }\end{array}$ & Data sekunder Biro Statistik & $\begin{array}{c}\text { 359.765kasus dari } 10 \text { area } \\
1985-1988\end{array}$ & Pengaruh faktor yang signifikan \\
\hline $\begin{array}{l}\text { Wiegmann dan Shappell } \\
\text { (2007) }\end{array}$ & $\begin{array}{l}\text { Penerapan klasifikasi kesalahan } \\
\text { manusia pada transportasi udara }\end{array}$ & HFACS & $\begin{array}{l}\text { Pegawai Federal Air Regulation } \\
\text { (FAR) }\end{array}$ & 119 laporan kecelakaan & Klasifikasi kesalahan manusia \\
\hline $\begin{array}{l}\text { Berlin,C., Ortengren,R., } \\
\text { Lamkull,D., \& Hanson.L, } \\
\text { (2009) }\end{array}$ & Studi komparasi prosedur evaluasi & $\begin{array}{c}\text { Komparasi kuantitatif, } \\
\text { interview,statistik }\end{array}$ & 2Ergonomis & $\begin{array}{l}\text { Standar Nasional \& Intemal } \\
\text { Corporate }\end{array}$ & BME-AFS-98 \\
\hline $\begin{array}{l}\text { Hamalainen,P.,Saarela, } \\
\text { K.J.Takala,J.(2009) }\end{array}$ & Strategi Interfensi Efektif & Perhitungan Statistik & Data5 tahun & Date WHO & Trend Global \\
\hline $\begin{array}{c}\text { Zakaria,Z,Hussin,Z.Hj, } \\
\text { Noordin,N.,\& Zakaria,Z. } \\
\text { (2010) }\end{array}$ & K3di lokasikonstruksi & SPSS & 100 orang & Kuesioner & Faktor kontributor kecelakaan \\
\hline $\begin{array}{c}\text { Village }, . \& \text { Ostry,A. } \\
(2010) \\
\end{array}$ & Pencegahan Cedera MSLs & Statistik & 691 orang & $\begin{array}{c}\text { Kuesioner Safety Climate } \\
\text { Checklist }\end{array}$ & Model Multi Varia \\
\hline M Ihsan Jambak(2011) & $\begin{array}{l}\text { Perancangan petunjuk pelaksanaan } \\
\text { penyelidikan faktor manusia pada } \\
\text { kecelakaan pesawat udara sipil di } \\
\text { Indonesia }\end{array}$ & HFACS & $\begin{array}{l}4 \text { orang responden dengan } \\
\text { kategoritertentu }\end{array}$ & $\begin{array}{c}\text { Laporan Final kecelakaan } \\
\text { pesawat terbang } \\
\text { bersumberkan date dari KNKT }\end{array}$ & Klasifikasi kesalahan manusia \\
\hline Eti H T (2011) & $\begin{array}{l}\text { Pengaruh aspek budaya terhadap } \\
\text { HFACS }\end{array}$ & HFACS & pilot garuda Idonesia & Quesioner HFACS budaya & deskripsiHFACS \\
\hline Wu, J,_\& Zhao, T.(2011) & Interaksi Manusia Mesin & C-HVACF & 2 Auditor & $\begin{array}{l}\text { Lap Kecelakaan Helikopter } \\
\text { Cina }\end{array}$ & Model Kecelakaan \\
\hline $\begin{array}{c}\text { Amick,B.C.,Menendez, } \\
\text { C.C.,Bazzanl,L, } \\
\text { Robertson,M.,DeRango } \\
\text { K.,Rooney, ,. \&Moore, } \\
\text { A.(2012) } \\
\end{array}$ & Efek Interfensi Ergonomik & $\begin{array}{l}\text { Uji Coba dan Model } \\
\text { Statistik }\end{array}$ & 78 orang & Tugas Group & Seleksi Kovariat \\
\hline $\begin{array}{c}\text { Yakubu,D.M.,\& Bakri, } \\
\text { I.M.(2013) } \\
\end{array}$ & Investigasikinerjakontraktor & SHASSIC & Laporan 2002-2010 & Kuesioner 3 tipe & DOSH \\
\hline $\begin{array}{l}\text { Yeow,P.H.P.,Yuen,Y. } \\
\text { Y.,\&Loo,W.H.(2013) }\end{array}$ & InvestigasikinerjaHSE kontraktor & SHASSIC & $\begin{array}{l}\text { Lebih dari } 40 \text { pekerja di setiap } \\
\text { lokasi 2002-2010 }\end{array}$ & DOSH 2011 & $\begin{array}{l}\text { Ranking } 3 \text { hazard telah } \\
\text { terdokumentasi }\end{array}$ \\
\hline
\end{tabular}

\subsection{Other Recommendations}

Wiegman and Shapell (2003) has developed a method to investigate the taxonomy of human error factor in the case of aircraft accidents and incidents called HFACS (Scott A. Shappel, 2000; Munoz,2018) following the Swiss Cheese Model (Reason,1990). Then adopted by other fields, namely shipping (Metin Celic, 2009), mining (Jessica M. Patterson, 2010), railways (Stephen Reinach, 2006; Munoz, 2018).

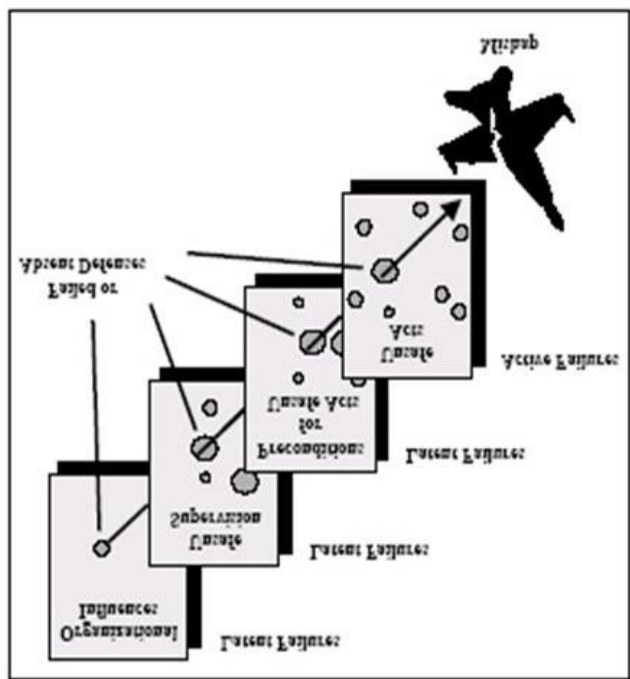




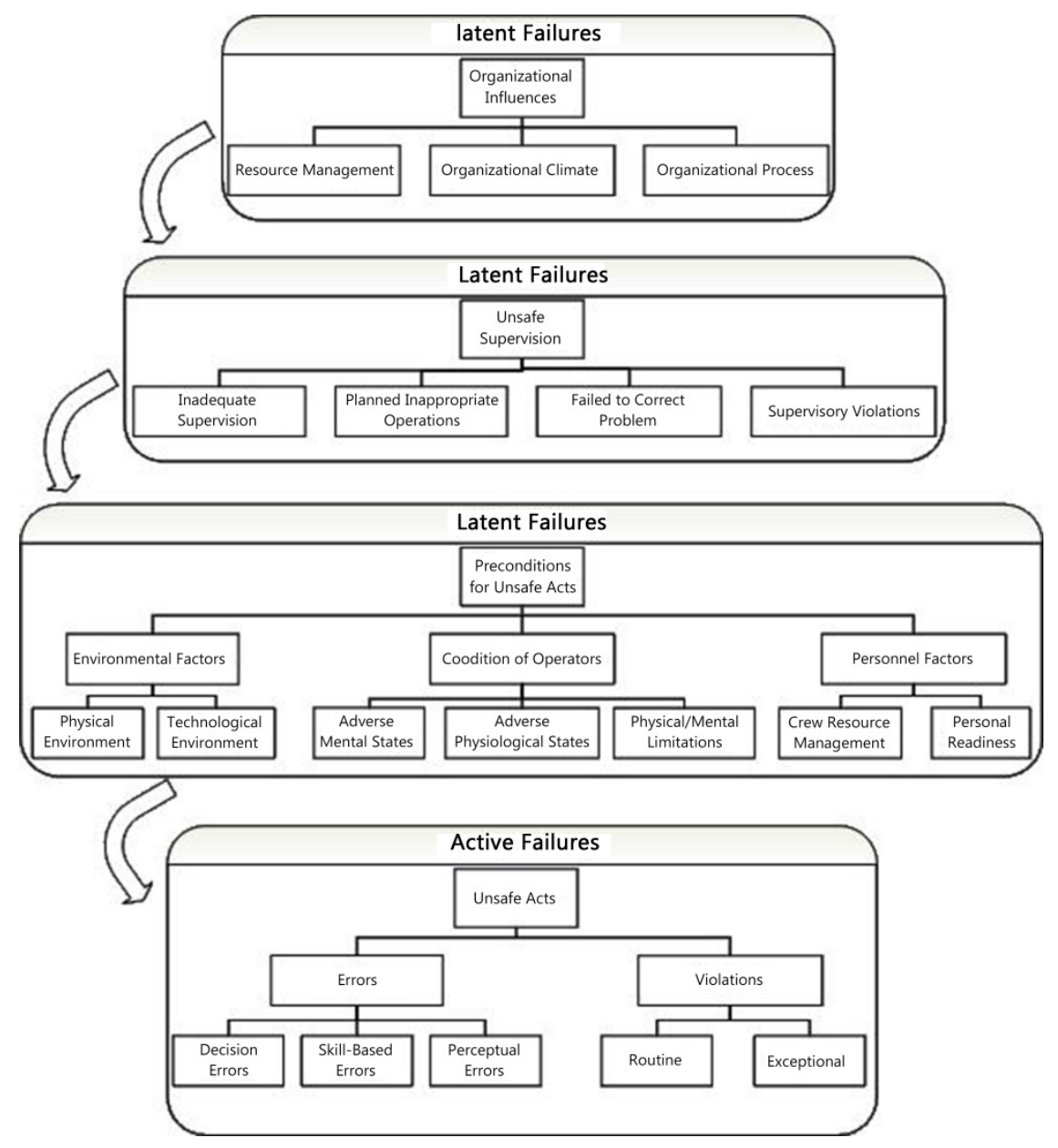

Selection method of investigation plays a crucial role, because each method has theories and concepts, each of which can produce output, focus on safety issues and different recommendations. In general, the accident investigation includes evidence collection, analysis, development of conclusions and reporting.

\section{Discussion}

The interaction between man and the various elements of the work are the main focus of the study of ergonomics that put forward the concept of human-centered design. If we examine more deeply, the human itself consists of several elements that interact to form a complex network system. Human beings have weaknesses and limits that are blending between them, raises error (human error).

In a simple human error is a specific variety of human performance which is reviewed from a clear unequivocal standards and defect performance retrospect based on a performance standard that is clearly done or omitted (Budiawan, 2010).

The definition of "human error" can be viewed from different angles. (Reason, 1997) gives direction to human error classification is based on four things:

- Intention

The study of human error by mental process.

\section{- Action}

The review is based on acts committed prior to human error.

\section{- Outcome}

The review is based on the level of probability of occurrence and the consequences resulting intensity level.

\section{- Context}

The review is based on a contextual event where cognitive factors become one of the most influential psychological aspects (Budiawan, 2010).

Stanton stated that one way to analyze human error is the identification of human error. This process is known as Human Error Identification (HEI) (C. Baber, NA Stanton, 1996). HEI is generally used as one of the aspects to be considered in designing the work system. This was done in order to minimize mismatches due to system error appears. Budiawan (2010) stated that the output of the HEI will provide knowledge to an analyst among other things;

- Potentials error that may occur. 
- The intensity of the consequences if an error occurs.

- The need for recovery efforts.

- The level of probability of error that occurred.

- Posed critical level.

- $\quad$ Error reduction strategies.
Wiegman, Shapell \& Associates (WSA) makes HFIX as intervention strategies using the mapping tool identification form human error analysis of HFACS and HFIX allow users to systematically build a comprehensive intervention strategy to achieve the target the cause of human error that is in the system.

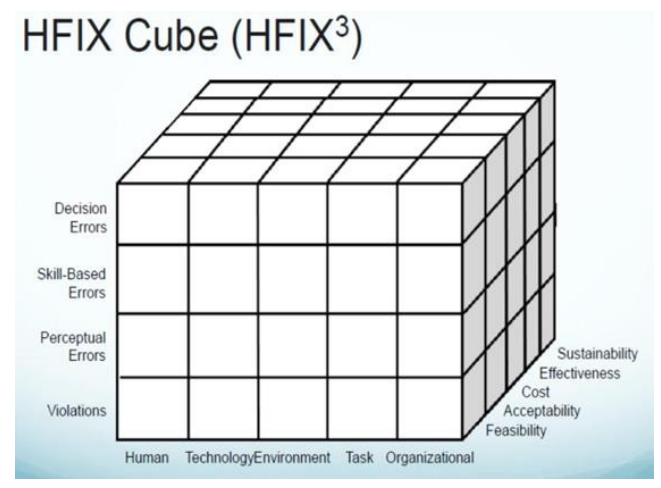

FMARI modified HFIX applications (computerized version of HFACS) and not all nanocodes used in Indonesia.

\begin{tabular}{|c|c|c|c|}
\hline \multicolumn{3}{|r|}{ Unsafe Acts (Tindakan yang Tidak Aman) - (CA) } & WARE \\
\hline \multirow{26}{*}{ 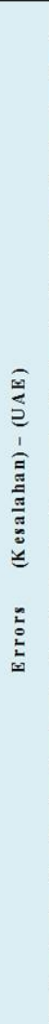 } & & Decision Errors (Kesalahan dalam Pengambilan Keputusan) - (TAE1II) & \\
\hline & UAE101 & Risk Assessment During Operation (Kesalahan Pengevaluasian Penilaim Resiko Selama Proses Pengoperssian) & Human \\
\hline & UAE102 & Task Mispriontization (Kes lah an Mempriontaskan Tug as) & Human \\
\hline & LAE103 & Necessary Action - Rushed(Kesalahan dalamBertindak - Tergesa-gesa) & Human \\
\hline & LAE104 & Necessary Action - Delayed (Kesalhan dalam Bertindak-Terlambat) & Human \\
\hline & LAE105 & Caution W W aming - Ignored( (Kes alhan dalam Mengabaikan Peringatan Kevasppadan) & Human \\
\hline & LAE106 & Decision - Making During Operation (Kesalahan Pengambialan Keputusun Sel ma Proses Pengoperasian) & Human \\
\hline & \multicolumn{3}{|c|}{ Skill-Based Errors (Kesalahan ỵang Diakibatkan oleh Kemampuan Dasar) - (CAE2rx) } \\
\hline & UAE201 & 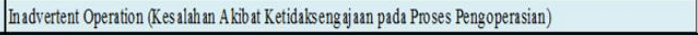 & Human \\
\hline & UAE202 & Checklist Eror(Kesalahnn Menggunakn DaftarPerkssa) & Human \\
\hline & LAE203 & Procedural Emor (Kesalahan pada Prosedur) & Human \\
\hline & CAE204 & Overcontrol Undercontrol (Kesal han Pengendalian) & Human \\
\hline & CAE205 & Breakdown in Visual Scan (Kesalahan Akbat Kerusakan pada Alat Visual) & Human \\
\hline & LAE206 & Poor Technique (Kesalahan Akbat Teknikyang Buruk) & Human \\
\hline & \multicolumn{3}{|c|}{ Perceptual Frrors (Kesalahan yang Diakibatkan oleh Persepsi) - (UAE3II) } \\
\hline & UAE301 & Error due to Misperception (Kesalahan Akbat Adanya Kesalahp ah aman) & Human \\
\hline & TAE302 & Visual Illusion (Kesalhhan Akbot Iusi Penglihatan Visual) & Human \\
\hline & LAE303 & Vestibular Ilusion (Kesalhan Akbat Iusi Keseimbangan) & Human \\
\hline & LAE304 & Missead Instument (Kesalahan pada Pembaccan Peralatan) & Human \\
\hline & LAE305 & Eppectancy (Kesalahan Akbat Pengh arap an Harapan) & Human \\
\hline & LAE306 & Auditory Ques (Kes slahan Akbat Isyarat Pendengaran) & Human \\
\hline & LAE307 & Temporal Distortion (Kes lahan Akbat Distorsi Sementara) & Human \\
\hline & LAE308 & 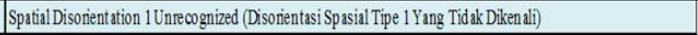 & Human \\
\hline & TAE309 & Spptial Disorientation 2 Unrecognized (Disorientssi Sp s ssial Tipe 2 Yang Tidak Diken ali) & Human \\
\hline & CAE310 & Spatial Disonentatation 3Incypactatting (Disonientasi Spasial Tipe 3) & Human \\
\hline & LAE311 & Misperception of Operational Conditions (Kes alahan Akbat Kes alahpahaman pada Kondisi Operasional) & Human \\
\hline \multirow{6}{*}{ 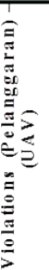 } & \multicolumn{3}{|c|}{ Routine Violations (Pelanggaran Rutin) - (CAV1xx) } \\
\hline & TAV101 & Routine Widespread (Pelanggarna yang Bersift Rutin Nenyelunuh) & Human \\
\hline & taV102 & Based on Risk Assassment (Pelanggrann Berdus arkan Peniziain akan Resiko) & Human \\
\hline & & & \\
\hline & \multicolumn{3}{|c|}{ Exceptional Violations (Pelanggaran yang Bersifiat Tidak Biasa) - (TAV2rx) } \\
\hline & AV201 & Lack of Discipline (Pelanggaran A Abibat Kurangnya Kedisiplinnn) & Human \\
\hline
\end{tabular}

There is no statistical evidence on the economic level with low safety position will be more competitive, but ILO states that countries are at a high level of job security will also have the level of competition at the most good. 


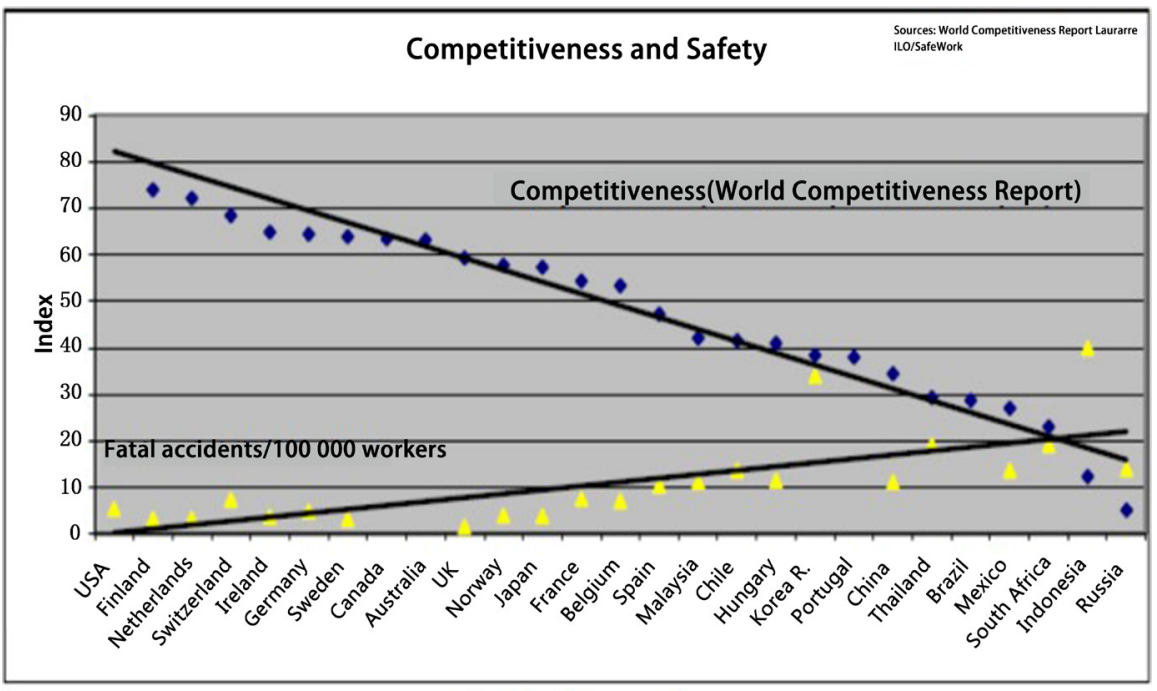

Figure 2. Competitive Safety Ranging (ILO, 2003)

In the early 1980s emerged a new view of health and safety at work, namely Behavioral Safety. Behavioral safety is the systematic application of psychological research on human behavior on the issue of safety in the workplace. Behavioral emphasize safety aspects of human behavior to the occurrence of accidents in the workplace. Suizer (1999), one practitioner Behavioral Safety suggests that practitioners have forgotten the main aspects of safety in preventing accidents that behavioral aspects of the workers. This statement is reinforced by the opinions Dominic Cooper. Cooper (1999) argues although difficult to control precisely, 80-95 percent of all workplace accidents that occur are caused by unsafe behavior. Cooper opinion is supported by the results of research of NCS on the causes of accidents. NCS research results show that $88 \%$ of causes of accidents are the unsafe behavior, $10 \%$ due to unsafe condition and $2 \%$ of unknown cause. Another study conducted by DuPont Company showed that $96 \%$ of workplace accidents are caused by unsafe behavior and $4 \%$ are caused by unsafe condition.

Unsafe behavior is the type of behavior that leads to accidents such works regardless of safety, do the job without permission, get rid of safety equipment, work operations at a breakneck pace, using non-standard equipment, abusiveness, lack of knowledge, disability or emotional state that impaired (Miner, 1994). According Suizer increase safety rules; safety training; an increase in the means of production; disciplinary and others have not been enough to prevent accidents. Changes obtained cannot last long because the workers back on old habits that unsafe behavior. Based on the reference that unsafe behavior is the biggest contributor to accidents then to reduce workplace accidents and to improve safety performance can only be achieved by focusing efforts on reducing unsafe behavior. Focus on unsafe behavior also results in better index of the safety performance in the company than focusing on the number of work accidents. It is based on two grounds, namely: occupational accident is the end result of a spate of unsafe behavior and unsafe behavior can be measured every day in a certain way. If the company is focused on the number of accidents, SMS tends reactive. Companies only pay attention to safety if the accidents increase. Instead behavioral safety approach tends to be proactive, because with this approach companies tend to try to identify any unsafe behavior that appears, so it can be directly addressed.

\section{Accident Case Study}

Based on information from various news sources, on Tuesday, February 12, 2013 around 10:00 am, some of the workers are in charge of making four holes for waste disposal at Basement Floor II. In one hole, there are four officers who do the work are two main officers (under) and mid- level officers (located above). While, making the hole is almost complete, just finishing removing the iron frame and cast the former boards to be painted.

On the fourth hole according to Standard Operating Procedures there are two workers who were on top and two workers at the bottom. But moments later, the hole heard two workers (workers 1 and 2) that were in the hole to ask for help. So that the two workers in the above (employee 3 and 4) down into the hole to help the workers who are in the hole. 


\begin{tabular}{|c|c|c|c|c|}
\hline$\frac{\text { Description of }}{\underline{\text { incident }}}$ & $\frac{\frac{\text { Categories of contact }}{\text { that could have led to }}}{\underline{\text { the indent }}}$ & Immediate Cause & Basic cause & $\begin{array}{c}\text { Activities for a } \\
\text { successful loss } \\
\text { control program }\end{array}$ \\
\hline $\begin{array}{c}\text { Poisoning gas/ } \\
\text { defisiensi oxygen }\end{array}$ & $\begin{array}{l}\text { Knotak dengan } \\
\text { Gas poisonous }\end{array}$ & $\begin{array}{c}\frac{\text { Substandard Act }}{\text { Failure to Secure }} \\
\text { Failure to use PPE } \\
\text { properly } \\
\frac{\text { Substandard }}{\text { Condition }} \\
\text { Hazardous } \\
\text { Environmental } \\
\text { Condition } \\
\text { improperly PPE }\end{array}$ & 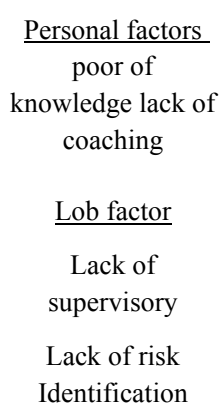 & $\begin{array}{c}\text { Properly and } \\
\text { adequate blower } \\
\text { Harness }\end{array}$ \\
\hline
\end{tabular}

Then two rescue workers who had come to ask for help because of difficulty breathing. A worker (workers 5) in the other hole up to cry, and then tried to help four colleagues. The worker is assisted by other workers (workers 6) and one clerk K3. Officers K3, 5 workers and assisted one another worker (worker 7) down to the bottom, while six officers kept vigil above. Then they cried again and fainted. So then a man officer of PT. Wxxx helped rescue using an oxygen mask and blower. They managed to evacuate a person. Officers of PT Wxxx that helped claimed limp. Then they replaced other officers, evacuate four other workers. Victims who had been evacuated seven people. Five people died and two people critical. Health Safety Executive, United Kingdom (2001) paparkan bahwa The Systematic Cause Analysis Technique (SCAT) is a method which has been developed by the International Loss Control Institute (ILCI), which can be used to determine the root causes of an incident once a description of the sequence of events has been determined. A paper describing SCAT by Bird and Germain (1985) is reproduced in a manual by ILCI (1989). Following the incident with the scheme SCAT method:

Scheme above is overview of the analysis of accidents that occur. Predicted the case of occupational accidents is a type of gas poisoning. Some of the symptoms showed any indication of gas poisoning that workers experiencing weakness in the body, shortness of breath and eventually unconsciousness. Besides, this suspicion is reinforced by the characteristics of the work environment in the form of Confined Space. Greatest risks in the workplace Confined Space is poisoning gas.

In the second case there is a block that contains a variety of things can lead to accidents. In the case of contact with poisonous gas is inevitable. This condition can be derived from the facts.

Among the release dangerous gases resulting difficulty breathe workers, workers are not equipped with gas detectors and the ability to use it, do not appropriate identification, and more.
In the third box is the immediate cause (direct cause) of the accident. There are two categories, namely ratings substandard conditions act and substandard. Substandard Act in this case, at least there are two main points of the points that we write SCAT diagram that failure to secure the working conditions and the workers themselves as well as the failure of workers in the use of PPE. Failure to secure in this case the victim is not protected from the risk of exposure to dangerous gases. Failure to use PPE Properly means victims do not use PPE properly. In the news, it did not mention whether workers using PPE such as respirators or not, only mentioned that the project has provided one blower for each hole.

In the fourth box, there is Basic Cause (basic cause) that contains Personal Factor and Factor Job. Personal Factor includes the Poor of Knowledge and Lack of Coaching. Poor of Knowledge means that workers and HSE officers do not yet have sufficient knowledge to perform tasks at confined space. Director General Labour Inspection Guidance No.Kep / 113 / DJPPK / IX / 2006 is set on who is allowed to work in confined spaces there is even a certain criteria that must be met to work in the confined space. Also in the news is mentioned that there was one officer who became a victim K3. This shows that the Human Resources Officer K3 especially do not know the standard first aid in an accident. Some officers K3 in the Company no competence appropriate background so that the competencies acquired during the training only General K3 or K3 specialization approximately less than a week. Victims should be able to be more and more reduced in number.

Job factors include Lack of supervisory and Lack of risk identification. It is clear that there was negligence in upholding the culture of $\mathrm{K} 3$ in the neighborhood. K3 officers with one of its functions is to identify the danger of omission by not detecting the presence of dangerous gases so that control measures do not exactly.

In the fifth box, it discusses what you can do to succeed Loss Control Program. Some recommendations are 
equipped workers with Gas Detector, Blower right and Harness. However, the most important thing is to revitalize $\mathrm{K} 3$ on the project workers and equip workers with adequate knowledge about $\mathrm{K} 3$ so as to enhance the action of safe work. The employee or officer K3 / HSE must be qualified in the work.

In this accident evenly and systemic errors, not only the environment but the supervision and implementation of K3 were seen as insufficient.

FMARI analysis in PT Wxxx accident is:

1) For Error Type: Errors, Violations, Environmental Factors, Operator Condition Factor, Personnel, Supervision Less, SOP unplanned, Solutions fails, Management, Human Resources and Climate and Cultural Organization dominant.

2) Analysis FMARI for Mode Type: UNSAFE ACT where UAE1 $\mathrm{xx}$ value at 15 .

3) Analysis FMARI for Preconditions Error Type: PCO2xx a value of 28 .

4) For FMARI Analysis Error Type UNSAFE SUPERVISION: USI1xx 16.

5) For FMARI analysis mode ORGANIZATIONAL PROCESS: Mistakes to achieve the greatest value in industry performance factor where efficiency is low because of the high cost of injury claims due to severe risk.

6) FMARI Analysis for Decision Making Errors: UAE105 reached a value of 5 for all industry performance factors.

7) Analysis FMARI for errors caused Foundational Skills: UAE203 achieve UAE202 5The value reached a value of 4 , while UAE204 value 2.

8) Analysis of error caused by the perceived FMARI: UAE311 value of 5 .

9) Analysis FMARI for Violations Routine: UAV101 inefficient in grades 5 .

10) Characteristically FMARI for Violation Analysis Offbeat: UAV201 value of 5.

11) FMARI Analysis for Environmental Technology: PEF206 reach a value of 3 .

12) Analysis FMARI Level Mental state: PCO101 and PCO111 value of 5 .

13) Analysis FMARI Level Physical State: PCO206, PCO210, PCO211, PCO212, PCO215 reached a value of 5 for all industry performance factors.

14) Analysis of Physical and Mental Limitations FMARI: PCO305 value of all five.

15) FMARI Analysis of Human Resource Management: PPF1xx vary.

16) Analysis FMARI Readiness Self Implementing Task: PPF2 $x x$ grades 1-2.

17) Analysis FMARI Oversight Insufficient: USIxxx value varies.

18) Analysis FMARI Planned Operations Less: USPxxx vary.
19) Failed FMARI Analysis Solving Problems: USF101, USF102 value of 5 .

20) Analysis FMARI Violations in Surveillance: USSxx value 5 (severe).

21) Analysis of Organizational Influence FMARI: OIR103 reach a value of 5 .

22) FMARI Analysis of Climate and Cultural Organization: OIC grades 3, OIP value 2 .

\section{Conclusions}

The design modifications Human Factors Intervention Matrix (HFIX) application form to Human Factors and Risk Analysis Industry (FMARI) is an effort HFACS visualization method is user-friendly and ease of entry or update data to all users in the field of occupational safety and health in Indonesia.

FMARI analysis on input of occupational accidents in the Waste Water Drainage Project Basement II was at the level: feasibility, acceptance, efficiency, efficient, and dominant at sustainability from significant nanocode. It was influenced by several factors, including:

- $\quad$ Errors, Violations, Environmental Factors, Operator Condition Factor, Personnel, Less Supervision, SOP unplanned, Solutions fails, Management, Human Resources and Climate and Cultural Organization shown to trigger an accident in Confined Space.

- Negligence of workers, work tools Completeness, Completeness of safety equipment, location altitude of work will also increase along with the percentage of completion of the project.

- K3 management improvement through intervention strategies at all levels, has contributed to a decrease in construction accidents and the government as the labor competency skills builder construction etc., set the Zero Accident program that must be met by all types of companies in a variety of fields.

Research that has been done is the first step for the implementation of evaluation and monitoring HFACS on SMS (SMK3) particularly construction services and other fields apart from military and transportation fields. Some of the alternative developments of FMARI include [9]:

- $\quad$ FMARI use as an open-source application and every SMK3 auditor especially in construction share findings from the field.

- The addition of such nominal input cost compensation for victims of accidents in the construction sector or the amount insurance companies imposed by BPJS.

- Database development FMARI of reports SMK3 / SMS manufacturing, oil and gas, automotive, chemical production derivatives and high-risk projects.

- Making FMARI applications based on Android to facilitate direct data entry shortly after the accident 
occurred so that the evidence in accordance with the report.

- $\quad$ FMARI with local language and make improvements toward development simulation scenario programming.

\section{Acknowledgements}

Authors wish to Mr. Iftikar Z Sutalaksana and BPJS for Employee, for his generous support and technical advice.

\section{REFERENCES}

[1] S. A. Shapell, D. A. Weigmann, "FAA final report: The Human Factors Analysis and Classification SystemHFACS”. Virginia: FAA, 2000.

[2] ICAO. Annex 6-3.2.4. Chicago: ICAO Press, 2009.

[3] M. Celic, "Analytical HFACS for investigating human errors in shipping accidents. Accident Analysis and Prevention 4", 2009, 66-75.

[4] J. M. Patterson, "Operator error and system deficiencies: Analysis of 508 mining incidents and accidents from Queensland, Australia using HFACS. Accident Analysis and Prevention 42", 2010, 1379-1385.

[5] A. V. S. Reinach, "Application of a human error framework to conduct train accident/incident investigations. Accident Analysis and Prevention 38", 2006, 396-406.

[6] D. A. Wiegmann, S. A. Shappell, C. Detwile, C. Holocomb, A. Boquet, "Human Error \& Comercial Aviation Accidents: an Analysis using The Human Factor Analysis and Classification System", Human Factors: The Journal of the Human Factors and Ergonomics Society 49, 2007, 227242.1

[7] W. Budiawan, Pengembangan Metodologi Analisis Human Error Dalam Meminimasi Kecelakaan Kereta Api. 2010, Bandung, ITB.

[8] C. Baber, N. A. Stanton, "Human error identification techniques applied to public technology: predictions compared with observed use", 1996, Applied Ergonomic vol 22, no 2, 119-131.

[9] Othman, R., Hossain, M. S., \& Jabarullah, N. H. (2017). Synthesis and characterization of iron - and nitrogen functionalized graphene catalysts for oxygen reduction reaction. Applied Organometallic Chemistry, 31(10), e3738.

[10] Minyamer, T., \& Belay, G. (2018). In Vitro Antibacterial Effects of Chloroform, Methanol and Water Extracts of Croton Macrostachyus Stem Bark Against Escherichia Coli and Staphylococcus Aureus Standard and Clinical Strains. The International Journal of Biotechnology, 7(1), 1-7.

[11] Munoz, A. (2018). A Security Scheme for Protecting Agent Societies. Review of Computer Engineering Research, 5(1), $1-11$. 